\title{
Discussion on the construction of "Double-qualified" teachers in Application-oriented Undergraduate Institutes
}

\author{
Zhan Haiyan
}

Shanxi Institute of International Trade \& Commerce, Xi'an, Shanxi, 712046

\begin{abstract}
Keywords: Application-oriented Undergraduate Institutes, "Double-qualified" teacher, countermeasures and suggestions
\end{abstract}

\begin{abstract}
The educational objective of Application-oriented Undergraduate Institutes is to cultivate application-oriented talents. It is an important guarantee to own a good team with noble morality, business skills, reasonable structure, full of vitality of the teachers in both theory and practice. However, the construction of the team in the Application-oriented Institutes is relatively weak. There exist common problems such as congnitive bias, standard vague, single selection approach, a little training effectiveness, imperfect system of assessment and incentive mechanismt, fewer special research achievements and so on. The paper will put forward some countermeasures and suggestions based on the objective analysis of above problems.
\end{abstract}

\section{应用型本科院校“双师双能型”教师队伍建设初探}

\author{
展海燕i \\ 陕西国际商贸学院, 陕西, 西安 712046 \\ 852566626@qq.com
}

关键词：应用型本科院校; “双师双能型” 教师; 对策建议;

摘要. 应用型本科院校以培养应用型高级专门人才为目标, 拥有一支师德高尚、业务精湛、 结构合理、充满活力的 “双师双能型” 教师队伍是实现人才培养目标的重要保障。然而, 当 前应用型本科院校这支队伍的建设整体比较薄弱, 普遍存在思想认识偏颇、认定标准比较模 糊、招录选用途径单一、培养培训实效性不强、考核激励机制不完善、专题研究成果少等问 题，本文在客观分析以上问题的基础上，提出了具体的对策建议。

\section{1 问题的提出}

2015 年 10 月 21 日，教育部、国家发展改革委、财政部联合发文《关于引导部分地方普 通本科高校向应用型转变的指导意见》（教发[2015]7 号）（以下简称《意见》）。《意见》 强调“推动转型发展高校把办学思路真正转到服务地方经济社会发展上来, 转到产教融合校企 合作上来，转到培养应用型技术技能型人才上来，转到增强学生就业创业能力上来，全面提 高学校服务区域经济社会发展和创新驱动发展的能力。”引导部分地方普通本科高校向应用型 转变, 实现应用型人才培养目标的关键之一拥有一支师德高尚、业务精湛、结构合理、充满 活力的高素质专业化教师队伍。对于应用型本科院校而言, “双师双能型” 教师队伍的建设 刻不容缓。

\section{2 应用型本科院校 “双师双能型” 教师的界定}

探讨应用型本科院校 “双师双能型” 教师队伍建设，需明确两个基本问题，一是应用型 
本科院校的定位, 二是 “双师双能型” 教师的定位。关于前者, 学术界有不同的见解。潘檚 元教授认为, 应用型本科院校的定位问题, 直接关系到我国高等教育应用型创新人才的培 养。应用型不是层次的高低, 而是类型的不同。国家应从宏观上进行分类指导, 促进高等教 育的多样化发展。笔者梳理现有认识发现, 对于应用型本科院校的定位, 其共同点体现在: 在培养目标上, 以培养应用型中高层技能型人才为主; 在培养层次上, 以本科生为主, 某些 特色学科可培养专业研究生; 在培养途径上, 主导以教学为主, 注重实践教学; 在培养特色 上, 以适应区域经济社会发展为导向, 突出学校特色品牌专业建设。综合以上特点, 本文认 为, 应用型大学指立足于服务地方区域经济社会发展, 服务行业需求, 以培养面向生产、服 务、管理一线的高级应用型人才为目标的本科院校。

关于 “双师双能型” 教师的内涵，应从两个方面来理解。一是从教师个体的角度，“双 师双能型” 教师实质上就是指具有 “双师双能素质” 的教师, 即要求教师既要取得教师资格 证书, 具有从事教育教学的基本资格条件, 又要具备行业要求的技能资格认定证明, 具有丰 富的行业职业实践素养。从能力方面来看, 要求教师不仅要具有系统扎实的专业理论知识和 较高的教育教学水平, 还要有丰富的实践教学经验和较强的专业实践能力。二是从教师整体 队伍结构来讲, 应用型大学要有相当比例的 “双师双能型” 教师, 这个合理比例的确定, 要 根据学校自身专业设置的特点和学校发展阶段的不同需求而定。

\section{3 应用型本科院校 “双师双能型” 教师队伍建设存在的问题}

目前，在国家政策大力推动和引导之下，应用型本科院校普遍都意识到 “双师双能型” 教师的数量和水平直接关系到人才培养的质量, 关系到学生就业质量的高低, 关系着学校长 期的生存和发展。因此, 各应用型大学都在此方面投入了一定的人力物力和财力, 开展了一 些较为扎实的工作, 以笔者所在院校为例, 在 “双师双能型” 师资队伍建设方面, 主要做了 以下方面的探索和实践: 一是改变过去比较单一的招聘路径, 开始面向企业和社会招聘具有 丰富的实战经验和精湛技能的中高层人才, 专兼职从事实践教学工作; 二是与校企合作单位 建立长期人才培养机制, 利用寒暑假选派部分青年骨干教师深入企业, 进行岗位实践锻炼, 提高其专业实践能力; 三是加强专职教师对学生实习实训的指导, 选派教师跟进学生实习实 训, 实行学生实习 “双导师”, 要求教师在跟进学生实习的过程中, 加强实践能力的培养; 四是将 “双师双能型” 教师的选聘与培养纳入学校整体队伍建设规划, 从战略上确定教师队 伍的可持续建设; 五是配套了一系列培养培训和激励考核机制, 改革薪酬体制, 加入 “双师 双能型” 教师的项目, 完善职称评审制度和考核机制, 将实践教学和能力提升作为评审和考 核重要指标; 六是加强对应用型办学定位的宣传和研讨, 增强全校师生员工对于应用型大学 的认识, 促使各部门和全体教师增强对 “双师双能型” 教师培养的高度认同和自觉践行; 七 是开展专题研究工作, 以项目推动、召开专题讨论等形式认真研究学校 “双师双能型” 教师 的招录选聘和培养培训工作。这些探索对于学校 “双师双能型” 教师队伍的建设起到了相当 大的推动工作, 也取得了一定的实效。但是, 从实践来看, “双师双能型” 教师队伍的建设 依然存在不少问题, 尚待解决。

\section{1 思想认识偏颇}

从笔者的走访调查来看, 部分应用型本科院校虽然定位于 “应用型” , 但实际上领导员 工对此认识不够深刻, 不够自信。尤其是部分领导和部分职能处室和基层教学单位的负责 人, 固化的思维模式影响着他们对于应用型大学的正确认识。比如他们常常会感觉到 “应用 型” 比 “学术型” 或 “研究型” 大学层次低, 社会认可度不高, 思想深处有追求 “高大上” 的意识, 对应用技术型人才培养的办学定位存在偏见, 因此在政策研读、理念宣传、专业设 置、教学管理、校企合作等方面不深入, 不细致, 没有将 “应用型人才培养” 的理念扎实贯 彻到各项具体工作中, 甚至有部分人还抱有观望的心态, 做一些表面文章。对于普通教师来 
说, 由于应用型本科院校大多数是新建院校, 教师队伍以 “青年教师” 为主, 而绝大多数青 年教师缺乏一定的企业社会经验, 他们对应用型技术专业的实践教学普遍认识不到位, 教学 改革的积极性不高, 自觉提高实践教学能力的意识不强。主要原因是他们长期接受的是传统 的学术型教学模式, 已有的思维观念和经验对他们影响较大。

\section{2认定标准比较模糊}

“双师双能型” 教师的招录选聘和考核, 难点之一就是认定标准问题。实践能力认定标准 往往难以量化, 因此, 导致各校在实际工作开展过程中面临很多难点。目前, 各校普遍运用 的做法是参考教育部高教司关于高校教师职称评审与其它专业技术职务评审的条件, 认为具 备讲师以上教师职称，又具备下列条件之一的专任教师为 “双师双能型” 教师：(1)有本专业 实际工作的中级 (或以上) 技术职称 (含行业特许的资格证书); (2)近 5 年有两年以上企业第一 线本专业实际工作经历, 或参加教育部组织的教师专业技能培训获得合格证书, 能全面指导学 生专业实践实训活动; (3)近 5 年主持 (或主要参与)两项应用技术研究，成果已被企业使用， 效益良好; (4)近 5 年主持 (或主要参与) 两项校内实践教学设施建设或提升技术水平的设计安 装工作, 使用效果好, 在省内同类院校中居先进水平。此资格认定标准具有一定的可操作性, 但由于缺乏与本校发展实际的紧密结合, 其认定缺乏一定的针对性, 而且, 各校现在普遍缺 乏后续培训考核的相关细化指标。

\section{3招录选用途径比较单一}

目前，整体上来说，应用型本科院校选聘 “双师双能型”教师，途径比较单一，实效性 不强。大多数学校面向社会招聘的范围比较狭窄, 主要是向校企合作企业部分招聘兼职教 师, 但往往标准比较模糊, 不仅数量有限而且相关的管理考核激励机制尚未建立, 合作单位 与学校之间不能形成有效的良性的长期的合作, 零散的、短期的人员兼职现象比较普遍。另 外, 部分学校的招聘还依然受传统的学术研究型大学的影响, 在教师的选择上过于重视教师 的学历、学校等, 比较青睐于各高校刚毕业的硕博研究生。而社会和企业中有较丰富经验的 人员, 常由于学历较低等原因, 被应用型院校拒之门外。

\section{4培养培训实效性不高}

教师专业实践能力的提升, 需要学校、企业和教师个人三方面的共同努力。目前, 各校 都开展了面向社会、企业的教师实践能力的培养培训工作。笔者所在的学校每年开展青年教 师暑期进企业实践锻炼的培训项目。经过培训, 确实收到了一部分成效。一方面, 增强了教 师对实践教学和应用型大学办学定位的进一步认识, 提高了教师参与社会、服务地方的觉 悟。另一方面, 教师参与企业的生产经营管理工作, 更进一步地融洽了学校与企业的关系, 使校企合作的深度进一步提高, 增强了双方的良性互动和协同发展。但是, 在实践中也存在 一些问题。主要有: 少数教师的认识和积极性不高, 学习主动性不强; 部分教学单位引导、 跟踪、指导和服务不到位, 组织管理不严格; 校企双方长期进行师资培养培训的制度不够细 化, 需进一步完善。

\section{5考核激励机制不完善}

虽然大多数应用型院校都有针对 “双师双能型” 教师的薪酬项目设置，但整体上来看， 体现不明显, 此项目薪酬比例占薪酬总额的比例低, 激励作用发挥不显著。同时, 在教师考 核中, 缺少比较科学系统的针对教师实践教学能力的考核, 部分学校对此项进行了考核, 但 考核执行不够细致, 流于形式的现象比较严重。这两方面具体政策的制定和实施是影响学校 “双师双能型” 教师队伍建设的关键。

\section{6专题研究薄弱}

由于大多数应用型院校都是新建本科院校, 历史积累相对比较薄弱, 内涵建设尚待增 
强, 学校整体的科学研究水平不高, 因此, 针对 “双师双能型” 教师队伍建设的专题研究更 显薄弱。笔者所在学校的科研部门、人力资源处、教师发展中心等以项目申报、专题研讨形 式进行了一些探讨, 但整体上来说, 参与人员少, 研究成果少, 没有在全校形成共识, 未能 激发各部门对于应用型院校师资队伍建设探讨和研究的氛围, 而此项工作的有效开展必须基 于全员的关注、探讨和实践。

\section{4 促进应用型本科院校 “双师双能型” 教师队伍建设的几点建议}

\section{1增强全员自信，坚定应用型办学理念}

理念是行动的先导。应用型本科院校的决策层首先必须深刻理解其办学定位, 要彻底改 变过去学术型大学的办学思路的困扰, 厘清思路, 锐意改革。要在全校范围内开展扎实有效 的教育观念大讨论, 要加大对各部门主要负责人的思想引导, 要将应用型大学的办学定位严 格贯彻到专业建设、教学改革、学生管理等各个环节, 主要领导要有办学自信, 坚定应用型 大学办学方向。同时, 要通过广泛的媒体宣传、专题研讨会等形式, 使应用型办学理念深入 每一位教师的脑髓, 引导、鼓励教师锐意进行教学改革, 探索研究应用型人才培养的实际问 题。

\section{2明确认定考核标准，增强教师 “双师双能” 自觉意识}

首先, 各校应根据本校专业建设需求以及教师队伍的实际情况, 参考国家有关教师职称 评审以及相关专业行业技术职务评审条件, 制定适合各校实际的 “双师双能型” 教师认定标 准。认定要体现职业性、专业性, 体现办学特点、专业特色等。其次, 重视对过程的考核, 细化 “双师双能型” 教师考核指标体系，加强教师指导学生实习实训的指导效果的客观评 价, 加强教师参加社会企业实践的过程考核, 加强教师进行实践教学改革与研究的细化考 核, 并积极将考核结果运用于教师的职称评审、评优评奖等方面, 通过考核提高教师进行自 我实践能力培养的自觉性和积极性。

\section{3拓宽招录选用渠道, 优化师资队伍结构}

针对当前应用型本科院校 “双师双能型” 教师队伍人数量少, 质量不高的实际, 各校应 积极拓宽招录选用渠道。在引进人才方面, 要积极转变观念, 以应用型大学的办学定位指导 人才招聘工作。面向社会广泛招聘, 不拘泥于校企合作单位; 根据学校发展需要, 合理确定 专兼职人员结构, 用工形式可以灵活多样; 以项目推动、任务完成为导向, 管理方式要创 新; 根据社会和行业情况, 合理确定社会招聘来的教师的薪酬待遇, 尤其是对优秀的社会企 业人士要敢于引进, 充分发挥他们的辐射带动作用。在此, 需要强调的是, 队伍建设初期, 部分学校往往急于求成, 注重数量忽视了质量, 笔者认为此做法欠妥, 教师队伍质量的高低 入口很关键, 初期建设是否严格, 后续影响很大, 人事部门务必高度重视招聘质量, 严把质 量关, 要有宁缺冊滥的意识。

\section{4加强主渠道建设, 注重培养实效性}

一方面, 应用型本科院校要加强 “外引”工作, 优化教师队伍的结构; 另一方面, 更要 注重自有教师的培养培训。提高学校 “双师双能型” 教师的整体质量, 关键还要依靠自有的 专职教师, “内培” 工作显得尤为重要。如何做好这项工作? 笔者认为, 要加强三方面的主 渠道建设。一是走出去, 学校通过制度要求和组织推动, 引导青年骨干教师走向社会, 走进 企业, 接受实践锻炼。具体来说, 学校每年可以利用寒暑假等时间, 安排教师到与专业相关 的单位, 通过挂职顶岗、合作研发等多种形式使教师拓宽视野, 了解社会, 丰富实践经验, 强化实践技能, 提高双师素质; 二是引进来, 通过外引的优秀的 “双师双能型” 教师的带 动、指导和帮助, 提高自有教师的专业实践能力和教学能力; 三是加强学校内部、校际之间 
的合作与交流, 有条件的学校也可以派出一部分骨干教师走出国门, 去国外院校或者优秀企 业进行学习。队伍建设初期, 学校应充分利用好校企合作的资源, 首先做好做实与校企合作 单位的人才培养工作，在协作共赢的原则下建立长期有效的合作机制。

\section{5健全评价激励机制, 激发教师内在动力}

建设优秀的 “双师双能型” 教师队伍, 激励引导很重要。应用型本科院校在薪酬结构 设置、标准制定以及考核方面应充分考虑到这一项目的重要性。首先, 薪酬结构中要有 “双 师双能型” 这一项目, 然后, 根据学校实际情况, 确定合理的项目标准, 要注意该标准在整 体结构中的合理比例问题。再次, 要有详细的考核体系, 考核项目中要重视教师参与社会实 践的频次及质量, 重视教师指导学生进行实习实训的数量及质量, 重视教师实践教学改革成 果的数量及质量等, 重视过程管理和目标考核。最后, 建议将 “双师双能型” 教师能力的认 定和考核纳入教师年度考核和职称评审中，以制度激励和引导教师主动提高实践教学能力。

\section{6加强专题研究, 提高队伍建设质量}

对于大多数应用型本科院校来说，师资队伍建设一直是一个薄弱之处，而 “双师双能 型” 教师队伍的建设更是面临很多困难。长期以来，该类院校师资队伍呈现出的 “两头大， 中间小” 的状况难以破解。老教师习惯于传统的教育教学方式, 无心或者无力加强自身实践 教学能力的提高; 年轻教师多是直接来自于学校, 缺乏一定的社会实践经验。这本身就是一 个难题, 需要深入研究。而目前学术界对此方面的研究整体比较匮乏, 已有的研究也比较笼 统, 且要么基于传统的本科院校, 要不基于高职院校, 专题研究应用型本科院校的成果少, 相关研究提出的对策建议针对性和可操心性也不强。因此, 笔者认为, 要真正提高应用型本 科院校 “双师双能型” 教师队伍建设的质量, 研究工作一定要跟上。学校自身要结合办学定 位、办学特色等进行专题研究, 建议从三方面着手: 一是各级科研项目的申报, 要注重应用 性导向, 注重项目与区域经济社会发展相结合, 与行业企业相结合, 与学校专业建设人才培 养实际相结合; 二是教学改革要重视实践教学, 完善学校在专业建设、课程建设、课堂管 理、质量控制等方面的相关制度, 增加学校对实践教学的经费投入, 鼓励教师积极参与实践 教学改革研究; 三是通过组织专题研讨会、学术交流会等探讨 “双师双能型” 教师队伍的建 设问题, 通过学术交流, 积极学习和借鉴兄弟院校优秀的研究成果和实践经验, 提高队伍建 设的专业化水平。

\section{基金项目:}

本文为陕西省教育厅项目 《民办高校青年教师能力提升的问题与对策-一基于陕西民办 高校的实证调研》 (编号: 16JK2030), 陕西国际商贸学院2016年校级科研项目《应用型本科 院校 “双师双能型”教师培养机制研究》中期研究成果。

\section{References}

[1]Pan Maoyaun,Research on the orientation of Application-oriented Undergraduate Institutes, Research Journal of Higher Education, vol 30,pp35-37,2009

[2]Zeng Yan,Research on the construction of "double quanlitied" teachers team in Application-oriented Undergraduate Institutes, Journal of Hubei Correspondence University, vol 29,pp9-10,2016 